$J J M L L$

\title{
Cognitive Models of Concepts Transformation in Some German Sports Terms Borrowed from English
}

\author{
Larisa Miroshnichenko*, Elena Musaelian \\ Department of Foreign Languages, Belgorod State National Research University, Russia \\ Larisa Voronina \\ Department of the German and French Languages, Belgorod State National Research University, Russia
}

Received on: 24-11-2019

Accepted on: 18-6-2020

\begin{abstract}
The article examines the linguistic aspects of the process of borrowing terms from the English language into the sports sphere of the German language from the perspective of a cognitive approach. It analyses the features of cognitive interaction of the conceptual systems of professional spheres. The paper describes transformation models of cognitive structures into the recipient language in the process of terminological borrowing on the material of sports Anglicisms of the German language. The study shows that loanwords most often convey a conceptual structure in the recipient language, which is generated on the basis of already existing mental structures in the source language. Various cognitive models of the transformation of the "alien" concept are defined: preserving the original structure of the prototype concept; developing new conceptual features in the recipient language; narrowing the conceptual structure of the concept prototype. The research contributes to the problem of the representation of knowledge in a term, the identification of linguistic and cognitive mechanisms of knowledge representation through borrowed linguistic units. The results can be used in the courses on cognitive linguistics, lexicology, in research practice and lexicographical descriptions, as well as in teaching practical language skills in professional sports.
\end{abstract}

Keywords: Borrowing, Terms, Sports Terminology, Cognitive Terminology, Professional Knowledge

\section{Introduction}

All languages in the world are subject to foreign language influence on the way of their development. The problem of language borrowing has a long tradition in linguistics. In numerous scientific works, the internal language mechanisms of this process were considered together with the problems of cultural-historical, socio-economic, and political contacts of countries and peoples. However, the cognitive vector of modern linguistic studies tends to analyze language phenomena in connection with conceptual systems that reflect the cognitive experience of native speakers at different stages, levels and aspects.

\footnotetext{
๑ 2021 JJMLL Publishers/Yarmouk University. All Rights Reserved,

${ }^{*}$ Doi: https://doi.org/10.47012/jjmll.13.1.3

*Corresponding author: miroshnichenko_l@bsu.edu.ru
} 


\section{Miroshnichenko, Musaelian, Voronina}

To study the cognitive foundations of the loan influence, a specific phenomenon was chosen - a terminological borrowing, which takes place in a professional environment. It is characterized by the emergence or structuring in a recipient language of a professional concept that evolves during a focused professional activity. This choice can be explained by the multidimensional nature of terms. In addition to the nominative and significant functions, terms perform a cognitive function - to reflect the process of cognition of the essence of objects and phenomena of the objective world and human activity. Terms are the main means of fixing, updating and broadcasting scientific and professional conceptual paradigms (Leychik 2012, 48).

Having considered the views on linguistic units borrowing within the traditional lexicology, as well as on the term definition and the peculiarities of its functioning from the standpoint of the cognitive approach, we realized that the problem of terminological borrowing, due to its depth and multidimensionality, is still challenging in modern linguistics. The intensification of the borrowing in the modern world make it necessary to study the deep-seated processes which provide the understanding of foreign terms in the recipient language in the system of professional knowledge, as well as the ratio of borrowed professional concepts, their labels (sports terms) of the recipient term systems and donor term systems.

The aim of the study is to determine the features of cognitive interaction of conceptual systems in professional spheres and to describe the cognitive models of the transformation of cognitive structures into the recipient language in the borrowing.

The object of the study is conceptual structures that are assigned to the concepts by the borrowed sports terms in the German language. The subject of the study is the cognitive structures transformation processes and the understanding of the terms in the system of competencies. We shall also consider the fact that borrowing implies, on the one hand, the ways to understand a foreign language terminology in a recipient language, and on the other, the identification of cognitive mechanisms. The latter determine the nature of professional concepts transformation verbalized by sports terms of the source language into the recipient language.

The material for the study is the defining of sports terms that are borrowed from the German language. The material choice is carried out by the continuous sampling from German and English specialized lexicographic sources, foreign vocabularies and defining dictionaries.

\section{Literature Review and Research Methods}

Fruitful scientific developments in the study of borrowing are associated with the works of Ogienko (1915), Efremov (1958), Superanskaya (1962), Sorokin (1965), Isserlin (1965), Maiorov (1967), Krysin (1968), Birzhakova (1972), Lotte (1982), Serebrennikov (1988), Marinov (2008), Betz (1974), Carstensen (1993), Polenz (1979, 1999), Weinreich (1979), Bußman (2002), Best (2001), Wohlgemuth (2009) and Eisenberg (2011).

Traditionally, borrowing is understood as a process of transfer, movement, and transition of words to other language. Thus, the Linguistic Encyclopedic Dictionary presents the following definition of "borrowing": "an element of a foreign language (word, morpheme, syntactic structure, etc.) that is 


\section{Cognitive Models of Concepts Transformation in Some German Sports Terms Borrowed from English}

transferred from one language to another as a result of language contacts, as well as the process of transition of one language elements to another" (Dobrodomov 1998). It should be noted that such transition does not occur mechanically. Any foreign language word is mastered by the system of the receiving language, and adapts it to its own needs on the formalistic and semantic levels.

The origins of these postulates were laid in the concept of Paul, who understood borrowing as one of the varieties of loan influence, that include foreign words in their native language. The usage of a native language for combining elements and adjusting to the content of the corresponding concept that is produced on "alien pattern" is attributed by the German linguist to a different kind of foreign language influence. Paul insists that words are always borrowed "in their entirety, derivational suffixes and endings are never borrowed" (Paul 1960, 469).

According to Krysin, it is the need to limit the term "borrowing" by indicating the structural level of the borrowed element and differentiating phonetic, morphological, syntactic, lexical and semantic borrowing (tracing). In his opinion, borrowing is "the process of transition of different elements from one language to another. By different he understands units of different levels of the language structure phonology, morphology, syntax, vocabulary, semantics" (Krysin 2004, 24).

The other view on the interpretation of borrowing is based on the notion of borrowing as a process of creating own elements using the means of the language "through creative imitation, approximate copying or structural modeling in analogy with foreign language samples" (Ilyina 1998, 91).

In 1950, Haugen for the first time distinguished between the phenomena of "transference" and "substitution" of foreign language elements that characterize the borrowing process, and proposed to divide the borrowing into "loanwords" and "loanshifts". In his later works, that were based on the classification of the German scientist Betz, Haugen adhered to the principle of the dichotomy of each type of borrowing and distinguished the following types of "foreign influence": 1. loanwords with partial or full transfer of a foreign morpheme, which are actually represented by the "pure loanwords"(without morphological substitution) and"loanblends" (with partial morphological substitution); 2. loanshifts (with substitution of native language morphemes), which include the creation (with transfer of the structure of a combination of morphemes) and extension (the structure is not transferred, but there is a phonetic, homologous or synonymous similarity with a foreign source) (Haugen 1972, 368-369).

In our opinion, the cognitive approach resolves the mentioned contradiction, when considering borrowing as a process of cognitive interaction of various conceptual systems. The theoretical basis for such a study is the basic principles of cognitive terminology and cognitive semantics, the theory of language conceptualization and categorization, and the theory of language representation, which was developed by Russian linguists (Golovanova, Leychik, Boldyrev, Kubryakova, Kasyanova, Khizhnyak).

In the process of thinking and verbal and cogitative activity, a person operates with certain units and structures that are informative operational units of knowledge. In cognitive linguistics, concepts are understood as units of the mental level. The content of the concept includes knowledge about objects, their characteristics, properties, that is, what "a person knows, thinks, assumes, imagines about objects of the world" (Pavilionis 1983, 102). 


\section{Miroshnichenko, Musaelian, Voronina}

It is obvious that "in the mother tongue there is a certain world view, <...> which it acquired in accordance with the fate of this language community, its geographical position and history, its spiritual and external conditions" (Weisgerber 2004, 107). Consequently, at the basis of the formation and development of national cultures there are different conceptual and linguistic worldviews, which are formed through various conceptualization mechanisms and verbalized by various linguistic means.

Yepimakhova notes that when people who belong to different linguocultures interact, not only words and expressions interchange, but also world categorization systems, cognitive bases that consider the borrowing process as a result of intercultural communication, which is a cognitive interaction, the exchange of concepts as elements of conceptual systems (Yepimachova 2011, 138).

In the framework of the cognitive approach, borrowing is considered as "the interaction of two conceptual spaces, that result in a borrowed concept or conceptual structure" (Golovanova 2011, 108). Borrowing involves the existence of a new concept in the recipient language or a change in the concept content (structuring) that already existed in the language. This process, along with the emergence of a new loanword with distinctive phonetic and graphic signs of the foreign language, acts as a translator of foreign cultural concepts, entails the emergence of new knowledge in the concept sphere of the recipient language.

As a result of cognitive interaction during borrowing, a new concept appears in the recipient language or the original concept is structured. For verbalization of these concepts in the recipient language, both foreign language nominees and their own language tools are used.

In modern cognitive terminology, the term is understood as a verbalized special concept that appears and improves the cognition process. Special concepts appear that are verbalized in discourse and give rise to terms in the process of cognition. Leychik gives the following definition of the term: "The term is a dynamic phenomenon that is born, formulated, deepens in the process of cognition, the transition from a concept - a mental category - to a verbalized concept associated with a particular theory, a concept that reflects a particular area knowledge and (or) activity" (Leychik 2012, 22). In this regard, the term can be considered as a verbalized special concept that appears and improves the process of cognition.

Novodranova notes that the cognitive essence of the term is determined by the peculiarities of the structure of knowledge, formed as a result of the cognitive activity of a specialist in a particular professional sphere. This structure is "the integration of several types of knowledge: knowledge about a certain fragment of the world (which includes encyclopedic, general scientific and actually special knowledge), knowledge about the mental forms of its reflection in the mind, about the linguistic forms of its representation, as well as knowledge of operating with linguistic units, the purpose of storing and transferring knowledge" (Novodranova 2012, 366).

The study of peculiarities of terminological borrowing in the cognitive perspective appeals to a different range of problems, including secondary nomination, the nature of terminology, conceptualization and categorization of knowledge, integrativeness of professional knowledge, etc. 


\section{Cognitive Models of Concepts Transformation in Some German}

Sports Terms Borrowed from English

The cognitive approach that we use to study the process of terminological borrowing explores borrowing in sports terminology of the German language not only in the way of traditional linguistics, but also within cognitive notions such as "concept", "conceptual structure", and "knowledge formats".

In our study, we take into account the complexity of the structural organization of the professional concept and the possibility of partially revealing its content by using language means of representation. Therefore, the focus is on the study of a type of concept that contains the most common, essential features of an object or phenomenon in a language. To highlight the conceptual features of a borrowed professional concept, definitional interpretations of borrowed sports terms are used, which are recorded in explanatory and specialized lexicographical sources of the German language.

Methods that are widely used in cognitive studies in linguistics are aimed at studying factual material: conceptual analysis, comparative analysis, as well as traditional linguistic methods of definitional analysis.

In this study hypothesis is that as a result of the cognitive interaction of conceptual spaces which are involved in the borrowing into sports terminology of the German language, the transformation of professional concepts and conceptual structures can be accompanied by preserving new and modifying old meanings in professional national cognitive spheres, for the verbalization of which are used both foreign language labels, and their own language means. The transformation of a borrowed professional concept can be carried out on the basis of various cognitive models.

\section{Results and Discussion}

The formation of any secondary sign in the language can be explained with the unit that is taken as the original one, or by deriving a new sign from it by applying certain mechanisms. Considering borrowing in the professional sphere, where the process of cognitive interaction of various conceptual systems takes place, we will take the initial unit of a professional concept or conceptual structure that functions in the donor language, that is, a concept prototype. The borrowing that performs a secondary representation transmits in the recipient language a conceptual structure generated on the basis of already existing mental structures in the donor language. Comparison of conceptual characteristics defined by conceptual analysis, professional concepts in the donor language and concepts verbalized by other language verbalizers in the recipient language allows us to distinguish the following cognitive transformation models of the "alien" concept:

- Preservation of the original structure of the concept prototype;

- Preservation of the original structure of the concept prototype with a change in the degree of the feature in the recipient language;

- Preservation of the original structure of the prototype concept and the development of new conceptual features in the host language;

- Narrowing the structure of the concept prototype. 


\section{Miroshnichenko, Musaelian, Voronina}

\subsection{Preservation of the original structure of the concept prototype}

When borrowing foreign sports terms, the professional concept in the recipient language can have are ciprocal conceptual structure in comparison with the analogue in the donor language. Using a comparative analysis of features that are based on a conceptual analysis of concepts borrowed in German and verbalized by a number of English sports terms, we define the nature of the relationship between the semantic structure of a professional concept in the donor language and the recipient language.

Drop|kick der; -s, -s <engl.>:

The Dropkick lexeme, which functions in German as a sports term, is a direct borrowing from English. In lexicographic sources, this lexeme in English dates to 1835-45 and is interpreted as «a kick made by dropping a ball to the ground and kicking it as it starts to bounce up» (The American Heritage Dictionary of the English Language, 5th ed., s.v. "drop kick”).

Modern English dictionaries define this lexeme as follows:

1. (Rugby) a kick in certain sports such as rugby, in which the ball is dropped and kicked as it bounces from the ground. Compare punt2, place kick.

2. (Wrestling) a wrestling attack, illegal in amateur wrestling, in which a wrestler leaps in the air and kicks his opponent in the face or body with both feet (Collins English Dictionary, s.v. "drop kick" accessed March 29, 2021).

- Drop kick (rugby league, rugby union) a kick of the ball when it bounces from the ground after being dropped from the kicker's hand; (wrestling) a kick made with both feet while jumping in the air (Room 2010).

In free encyclopedia Wikipedia, the following terminological meanings of the "drop kick" lexeme are indicated in the sports field: 1) a type of kick in rugby union, in various codes of football; 2) an attacking maneuver in professional wrestling (Wikipedia. The Free Encyclopedia, s.v. "Drop kick," last modified March 29, 2021).

The analysis of the given definitions makes it possible to distinguish the following conceptual characteristics associated with the "drop kick" lexeme in the English language: 'a type of kick', 'the act of delivering and the foot, 'round object after having struck a surface'; 'offensive moves', 'an athlete', 'a movement upwards or forwards, 'a contestant', 'with both feet', and

In German lexicographic sources, the Dropkick is defined as follows:

- Schuss (bes. Beim Fußball), bei dem der in Augenblick gespielt wird, in dem er auf den Boden aufprallt

(hit the ball (especially in football) when he hits the floor) (Duden, s.v. "Dropkick," accessed March 29, 2021);

- eine Schusstechnik im Fußball, bei der der Ball unmittelbar nach dem Aufsetzen auf dem Boden (englisch: to drop) geschossen wird (soccer strikes, in which the ball is struck directly after the floor touches it);

- eine Kampftechnik im Wrestling, bei der der Wrestler so in die Luft springt, dass er mit beiden Fußsohlen die Brust des Gegners trifft (wrestling fighting technique in which the wrestler makes a leap in the air and touches the feet of the opponent's chest); 
Cognitive Models of Concepts Transformation in Some German

Sports Terms Borrowed from English

- einen Sprungtritt im Rugby, bei dem, anders als im Fußball, der Ball vorher den Boden berühren muss, um gewertet werden zu können (hopping shot in rugby, in which, unlike football, it is estimated if the ball first touches the ground) (Wikipedia. Die freie Enzyklopädie, s.v. "Dropkick," last modified March 29, 2021).

The structure of DROPKICK concept forms the following conceptual features: 'Schusstechnik" (kicktecnique), 'das kräftige Fortstoßen' (repulsion by force), 'kugelförmiger Gegenstand' (an object of a circular shape),'auf Grundfläche stoßen“ (face the surface), 'jemandes Leistung bewerten“ (assess someone’s achievement); 'Technik des Kämpfens' (wrestling technique), 'Sportler' (athlete), 'Stoß mit dem Fuß` (kick), 'Körperbewegung' (body movement), 'berühren‘ (touch), 'gegnerischer Spieler' (rival player), 'zwei Füße' (two feet).

Comparative analysis of conceptual features in the source language and the recipient language shows that the borrowed conceptual structure of the concept DROPKICK has a similar composition compared to the prototype: 'a type of kick' $\rightarrow$ 'Schusstechnik', 'an attacking maneuver' $\rightarrow$ 'eine Kampftechnik'. The relationship between the conceptual content of the lexeme of the source language and the conceptual content of the lexeme of the recipient language is characterized as an equivalence relation.

Alike model of transformation is typical for concepts verbalized by the following sports terms:

der Assist (a player's action of helping to put out an opponent, score a goal); der Backspin (a backward motion imparted to a ball when struck, as in golf or snooker); der Basketball (1. a game played between teams of five players, the object being to toss the ball into the opponents' basket to score a goal; 2. the large inflated ball used in the game); der Back (a defensive player behind the forwards); die Baseline (a line that joins two bases); der Batter (the player with a bat who attempts to strike the ball delivered by the pitcher and score a run); der Beachvolleyball (a form of the game played barefoot on an outdoor sandy court between teams of two players); der Bọdycheck (the deliberate obstruction of an opposing player's movements); das Bogey (a score of one stroke over par for a hole); das Birdie (a score of one under par on a hole); der Bụnker (a hazard in the form of a Sand-filled hollow); fight (a Boxing or martial arts match); der check (the (legitimate) blocking of An opponent's forward progress with one's shoulder or hip); der dunking (a shot made by jumping up and pushing the ball down through the basket); der Eagle (a score of two strokes under par on a hole); das Fairway (the closely mown area of turf between the tee and the green, as distinct from the uncut rough or hazards); der/das Fastbreak (an attempt to score by moving the ball forward quickly after gaining possession); das Forechecking (a check made to an opponent in his own defensive area); der Goalkeeper (the player who defends the goal in a game such as association football); das Golden Goal (the first goal scored in extra time); das Gọlf (a game played with a club used to propel a ball into each hole on a course); die Halftime (the interval between the first half of a game and the second); der Hardcourt (a court laid with clay, cement, or the like, as distinct from a grass court); der Hattrick (three successes of any kind in any sport); der Hop (the first stage of the triple jump); der Hookshot (a shot made by a player side-on to the basket by curving up the arm farther away from it); das Hurling (an Irish game resembling hockey, played with a shorter stick with a broader oval 


\section{Miroshnichenko, Musaelian, Voronina}

blade); der Inlineskate (a type of roller skate in which the wheels are fixed in a single line along the sole); der Jab (a short straight punch); der Spurt (a sudden increase of speed or energy, as in a sprint) and others.

The given type of transformation of borrowed concepts is most illustrative for sports English loan words, as evidenced by the number of terms in this group.

\subsection{Preservation of the original structure of the concept prototype with a change in the degree of the trait}

A borrowed sports term can convey in the recipient language a conceptual structure equivalent to the corresponding structure in the donor language. The degree of singling out (dominance) a particular attribute in the recipient language can vary. Consider this fact on the example of a comparative conceptual analysis on the example of a sports loan term:

But|ter|fly ['bateflai] der; - [s], -s <engl.; "Schmetterling"

The lexeme "Butterfly", which is a direct borrowing from English, is used in German as a sports term and objectifies the style of swimming, the technique of performing gymnastic exercises and jumping in figure skating.

Etymological English dictionaries date the use of this lexeme in sports terminology to 1936 (Online Etymology Dictionary, s.v. "Butterfly," accessed March 29, 2021). The etymological source of this sporting term is the complex Old English word "buttorfleoge", whose component composition includes the nouns "butter" + "fly", meaning an insect, a representative of the order Lepidóptera (lepidopterius insects). In the metaphorical meaning, the lexeme "Butterfly" is widely used in the English language. So, according to the etymological dictionary, since 1600 it has been used to nominate people who dress without any taste. In 1806 different sources indicated the use of this word in relation to the transformation of the early forms of statehood. In 1908, the word also meant "light stomach spasms caused by anxiety." The process of terminology of this lexeme in the sports field was carried out in the language - donor.

In the sports terminology of the English language, the lexeme "Butterfly" was a means of nominating a new technique of swimming, developed by Iowa State University swimming coach David Armbrester in 1934. The proposed swimming technique, used in the breaststroke, contributed to the improvement of the method of extending the arms above the water. In 1935, swimmer Jack Zig developed a technique for moving his legs during wave-like body movement, which is used in swimming on his back and abdomen, nominating this style as a "dolphin". The combination of these techniques allowed us to develop a new style of swimming- the butterfly, which is the second place in speed after the crawl style.

Modern English dictionaries give the following definitions of the Butterfly lexeme:

1. Any of various insects of the order Lepidoptera, characteristically having slender bodies, knobbed antennae, and four broad, usually colorful wings.

2. A person interested principally in frivolous pleasure: a social butterfly.

3. Sports

a. A swimming stroke in which a swimmer lying face down draws both arms upward out of the water, thrusts them forward, and draws them back under the water in an hourglass design while performing a dolphin kick. 


\section{Cognitive Models of Concepts Transformation in Some German}

Sports Terms Borrowed from English

b. A race or a leg of a race in which this stroke is swum.

4. Butterflies: A feeling of unease or mild nausea caused especially by fearful anticipation (The American

Heritage Dictionary of the English Language, 5th ed., s.v. "Butterfly").

We would like to state that the sports term "Butterfly" is used in English to objectify the type of activity (swimming style) and at the same time represents the form of activity (competition that is performed by this swimming style); the formation of a secondary meaning is based on metonymic transfer according to the model VIEW - FORM.

In figure skating the word combination "Butterfly Jump" means "A flying spin with a two-foot takeoff. The body goes with the scissoring leg motion" (Wikipedia. The Free Encyclopedia, s.v. "Glossary of figure skating terms," last modified March 29, 2021).

Thus, according to lexicographic sources, we single out the following conceptual signs associated with the "Butterfly" lexeme: 'animals of the class Insecta', 'appon', 'enjoyment', 'physical condition", 'negative emotion'. As a sports term, this lexeme represents the following conceptual characteristics: 'swimmingstyle', 'athlete', 'the part of the body', 'movement along the circle of the circle', 'a contest of speed", 'the art of spin', 'a two-foot take off', 'horizontal position of a body", 'scissoring leg motion".

In the recipient language, according to the Duden dictionary of foreign words the borrowed lexeme "Butterfly" is used only as a sports term and is defined as follows:

1. Bestimmter Spreizsprung im Eiskunstlaufen (a certain jump in a twine in figure skating).

2. (Turnen) Salto seitwärts gestreckt, der von einem Bein gesprungen und auf dem anderen Bein (Schwungbein) aufgefangen wird ((gymnastics) somersaults, in which the torso is horizontal, the push is performed with one foot and the other leg (swing) is intercepted).

3. (ohne Plural) Butterflystil (butterfly style) (Duden, s.v. "Butterfly," accessed March 29, 2021).

In the dictionary of figure skating terms, the lexeme "Butterfly" is defined as "beliebter Eingang in Pirouetten, bei dem von der linken Zackenspitze abgesprungen wird. In der Flugphase befinden sich Oberkörper und Rumpf waagrecht zum Eis. Die Beine werden mit Hilfe einer scherenartigen Bewegung ebenfalls in waagrechte Position gebracht. Die Landung erfolgt auf der rechten Zackenspitze, was diverse Pirouetten im Anschluss ermöglicht. Ein Eingang in eine Pirouette ist aber nicht zwingend notwendig" (any transition to pirouette, in which repulsion is carried out with support on the left toe pick. In the flight phase, the torso must be parallel to the ice surface. The legs perform a "scissors" movement and are also parallel to the floor. Landing is carried out on the right toe pick, which allows you to perform various pirouettes. But the transition to the pirouette is optional) (Wikipedia. Die freie Enzyklopädie, s.v. "Eiskunstlaufelemente," last modified March 29, 2021).

This interpretation, supplementing the first definitional meaning of the Duden dictionary of foreign words, allows us to single out the following conceptual characteristics of the term: 'Sprung' (jump), 'horizontale Lage des Rumpfes' (horizontal position of the body)', 'gleichzeitiger Wechsel der Beine' (simultaneous change of legs), 'Abstoßung' (repel, touchdown), 'untere Gliedmaßen' (lower limbs), 'scharfes Ende des Schlittschuhes' (toe pick). Taking into consodaration the second definitional 


\section{Miroshnichenko, Musaelian, Voronina}

interpretation, the list can be enriched with the following features: 'frei in der Luftausgeführte Rolle des Körpers' (free body turning in the air).

In the third dictionary interpretation, the lexeme "Butterfly" is presented as a halfcalque for the "Butterflystil" and a synonym for the calque "Schmetterlingsstil" <Eng. "Butterfly style" (cf. Butterflystil der; - [e]s: Schmetterlingsstil (im Schwimmsport) (Duden, s.v. "Butterfly," accessed March 29, 2021).

In the German dictionary of the publishing house Brockhaus "Butterfly" is defined as "Sportschwimmart, Schmetterlingsschwimmen" (type of swimming, butterfly-style swimming) (Der Brockhaus in Text und Bild 2006, s.v. "Butterfly"). In turn, "Schmetterlingsschwimmen" has the following definitional interpretation:

Schmetterlingsschwimmen (Butterfly, Delphinschwimmen), Sportschwimmart, Ausführung in Brustlage mit symmetrischer Armführung über (nach vorn) und unter (nach hinten) Wasser, koordiniert mit vertikaler Rumpf-Bein-Bewegung, wobei der Impuls aus der Hüfte kommt (Delphinbewegung). Bei Meisterschaften über 100 und 200 m ausgetragen, seit 1956 auch bei Olympischen Spielen (swimming style, performed in position on the chest with symmetrical dilution of hands above (forward) and under (back) with water, associated with vertical movement of the body and legs, with impulse comes from the hip (dolphin movement). At championships it has been held at distances of 100 and $200 \mathrm{~m}$, since 1956 it has been included in the program of the Olympic Games) (Der Brockhaus in Text und Bild 2006, s.v. "Butterfly").

The analysis of German lexicographic sources allows us to highlight the following conceptual features of the BUTTERFLY concept: 'Art des Schwimmens' (swimming style), 'horizontale Lage des Rumpfes‘ (horizontal position).

The comparative analysis suggests that the recipient language borrows only a certain concept in the field of sports, the label of which is the foreign word "Butterfly". The semantic structure of the professional concept in the recipient language is equivalent to the semantic structure of the source language. However, there is a change in the degree of dominance of the feature: the conceptual feature in the English language 'a contest of speed' (competition for speed), which is updated in the dictionary definition 3b; in German it has the status of functional feature 'Sportlicher Wettkampf', that reflects the functional significance of the referent - swimming style.

This model is also individual for the concept verbalized by the term "der Football". In Britain, the term "football" refers to a game played between two teams of eleven people, where each team tries to win by kicking a ball into the other team's goal. In American English, the term "soccer" is used for the name of this game. In the United States, the term "football" is associated with a game for two teams of eleven players in which an oval ball is moved along the field by running with it or throwing it (American football). In addition, "football" nominates a large ball made of leather or plastic and filled with air, used in games of football. In German, the term "football" is a hyperonym in relation to the names of all sports that combine the features of football and Rugby (Gridiron Football, American Football, Canadian Football, Arena Football, etc.). This lexeme also nominates an oval ball for these games. Thus, the original structure of the concept existing in the American language community is preserved in German. 


\section{Cognitive Models of Concepts Transformation in Some German}

Sports Terms Borrowed from English

However, such conceptual signs as 'sports games from America', 'Canada', 'playing the ball with your hands', 'oval ball', combined in the encyclopedic zone of the concept in English, form the information content of the concept and reflect the most essential notes of the denotation in German.

3.3. Preservation of the original structure of the concept prototype and development of new conceptual signs

The borrowing of foreign terms can be carried out by preserving the original structure of the concept associated with the term in the donor language, with the further development of conceptual features in the adaptation process of the borrowed term in the recipient language. Let us consider this model comparing the results of the conceptual analysis of a sports foreign language term in the German language.

Spurt der; - [e] s, -s (selten: -e) <engl.>(Sport)

The lexeme "Spurt" was borrowed from English at the end of the 19th century. Duden's etymological dictionary defines the origin of this lexeme in German from the English noun "spurt" "plötzliche, ruckartige Bewegung, Anstrengung" (sudden movement, tension), which in turn is derived from the English verb "to spirt” (Duden, s.v. " Spurt," accessed March 29, 2021).

Modern English dictionaries give the following definition value of the lexeme in question:

spurt (sp3:t) or spirtvb

1. To gush or cause to gush forth in a sudden stream or jet

2. To make a sudden effort

3. A sudden forceful stream or jet

4. A short burst of activity, speed, or energy (Collins English Dictionary, s.v. "spurt" accessed March 29, 2021).

Based on lexicographic sources, we single out the conceptual signs of the concept SPURT: 'movement', 'size growth', 'credred unexpectedly', 'speed of movement', 'movement size', 'tension of forces', 'strong, bright manifestation of something', 'time', 'distanceness of objects from each other', 'short distance'.

In German dictionaries Anglitsizm "spurt" is interpreted as follows:

- Steigerung der Geschwindigkeit bei Rennen; äußerst schnelles Laufen über eine kürzere Strecke (increase in speed in races; very fast running at a short distance;

- schneller Lauf (fast running) (Duden, s.v. " Spurt," accessed March 29, 2021);

- äußerste Beschleunigung des Tempos, besonders vor dem Ziel eines Laufes, Rennens, in der

Schlussphase eines Wettkampfs (excessive acceleration of pace, especially before finishing the race, in the final stage of the competition) (DWDS, n.d.).

The analysis of dictionary definitions highlights the following conceptual features: 'Veränderung der Größe' (change in value), 'Bewegung‘ (movement), 'Änderung des Bewegungszustands' (change in the state of movement), 'Schnelligkeit' (speed), 'Intensiv, viel in kurzer Zeit', 'Wettkampf' (competition), 'geringe Entfernung' (short distance), 'letzte Phase' (last phase), 'Ergebnis' (result). 


\section{Miroshnichenko, Musaelian, Voronina}

Comparative analysis of the conceptual features of a borrowed lexeme in the donor language and the recipient language show a coincidence of some conceptual characteristics. They define the professional

concept: 'Bewegung' (movement), 'Änderung des Bewegungszustands' (change in the state of movement), and 'Schnelligkeit' (speed). The German professional concept is complemented by the conceptual signs 'intensiv, viel in kurzer Zeit', which are highlighted on the basis of the common meaning of the lexeme in English. The conceptual characteristics of 'letzte Phase' (last phase), 'Ergebnis' (result) detail the meaning associated with the corresponding verbalizer in the recipient language. In the German conceptual space, the sign of the 'suddenness of movement' associated with the SPURT nominator in English is not updated. We think that its absence is related to the planned and purposeful nature of an athlete's increase in speed in the final phase of the race, the technique and timeliness of which affects the result of the competition.

In the semantic assimilation of the term in German, a metonymic understanding of the movement is observed and is based on the "reason $\rightarrow$ result" cognitive model: 'Steigerung der Geschwindigkeit' (increase in speed) $\rightarrow$ 'schnelles Laufen' (fast run). Among other things, the lexeme "Spurt" is characterized in German with high word-building activity. Derivatives from this lexeme are: spurten, das Spurten, Schluss-Spurt, Spurtprämie, Spurtsieg, Spurtsieger, spurtschnell, spurtstark, Spurtvermögen, Zwischenspurt, Endspurt. From the sports sphere of use, this lexeme goes into the category of colloquial vocabulary and is used in the meaning of 'schneller Lauf, das Spurten' (fast run, rush).

\subsection{Narrowing the original structure of the prototype concept}

In the process of certain special concepts borrowing, there is no transformation of individual conceptual features that were in the donor language. This indicates the narrowing of the initial structure of the concept-prototype.

As an example we consider the sports term "Hattrick", which is a direct borrowing from the English language and is used in German in the golf, tennis terminology.

Hat|trick ['hetrik] der; -s, -s <engl.> (Sport)

The Hattrick lexeme is a direct borrowing from English and is a composite, the parts of which are English words "hat" and "trick". The Extended Oxford English Dictionary 1999 Edition indicates that the term came as a result of a cricket event when in Sheffield in 1878 a bowler called Heathfield Harman („HH”) Stephenson for the first time managed to make three successful consecutive blows that destroyed the wickets. As a result, the athlete received all the money earned for the match, and was awarded a hat. In 1878 , the term was used in the press to describe such tricks in football, handball and water polo (Wikipedia 2021).

Modern English dictionaries give the following definitions of the "hattrick":

1. Three goals scored by one player in one game, as in ice hockey.

2. Three wickets taken in cricket by a bowler in three consecutive balls.

3. Three consecutive wins or outstanding accomplishments by the same individual, such as a jockey in horse racing (The American Heritage Dictionary of the English Language, 5th ed., s.v. "hattrick"). 


\section{Cognitive Models of Concepts Transformation in Some German}

Sports Terms Borrowed from English

In the Random House Kernerman Webster's College Dictionary, these definitions are supplemented with the meaning of "a clever or adroitly deceptive maneuver" (Random House Kernerman Webster's College Dictionary, s.v. "hattrick").

Thus, the conceptual structure of HATTRICK is presented by the following characteristics: 'a sport result', 'three achievements', 'following one after another', 'one participant in a sport event', 'an equipment', 'an event consisting of various sporting contests', 'a misleading movement'.

In German dictionaries, the "Hattrick" is defined as:

- a) (besonders Fußball, Handball) Gesamtheit von drei in unmittelbarer Folge vom gleichen Spieler im gleichen Spielabschnitt erzielten Toren (especially football, handball) (a combination of three consecutive goals scored by one player for a certain period of time);

b) (Sport) dreimaliger Erfolg (in einer Meisterschaft o. Ä.) (three times success (in the championship, etc.) ((Duden, s.v. "Hattrick," accessed March 29, 2021);

- (Fußball) dreimaliger Torerfolg hintereinander in einer Halbzeit durch denselben Spieler (football)

(three consecutive goals by one player in the half) (Duden. Das Fremdwörterbuch, 10th ed., s.v. "Hattrick").

Thus, the structure of the "HATTRICK" concept is represented by the following conceptual characteristics: 'drei Treffer' (three goals scored), 'Aufeinanderfolge' (sequence), 'ein Wettbewerber' (one competitor), 'Zeitspanne eines Sportwettkampfes' (time period of the sporting competition), 'drei positive Ergebnisse‘ (three positive results).

Comparative analysis of conceptual features in the donor language and the recipient language shows that in the German conceptual space, the Hattrick lexeme is associated with a certain period of time during a sporting event. This means that three consecutive results must be achieved by a competitor in a more limited period of time than it is understood in the donor language, for example, 'in einer Halbzeit" (in one period) of a football match. In addition, in German football, Hattrick assumes that during this time there will be no goals scored by other competitors (including the opposing team). Consequently, in the recipient language, when borrowing, the concept is narrowed down according to a temporary basis in comparison with the donor language. The transfer of conceptual elements is carried out on the basis of the metonymic conceptual model 'whole $\rightarrow$ part', 'one game' $\rightarrow$ 'Spielabschnitt'.

The conceptual attribute 'drei positive Ergebnisse" (three positive results) served as the basis for using the "Hattrick" in German in a figurative sense in non-sports fields of activity for nominating threefold awards, prizes in the world of cinema, music and other cultural fields, as well as in computer games.

A corresponding model of concept transformation is observed in sports terms-the English loan words die Advantage, die Base, das Board, das Break, der Center, der Cross, der Cut, das Game, das Goal, das Green, etc.

For example, das Game in German in the sports sector is limited only to its use in the tennis sector and means a period of play, at the end of which there is usually a result or score game. The 'any sport' 


\section{Miroshnichenko, Musaelian, Voronina}

feature that conveys the information content of the English language GAME concept does not exist in German

\section{Conclusion}

This study has shown that the processes of globalization and internationalization of sport influence the development of the professional German sports system that is expressed in borrowing professional concepts and language units which are terminated in the donor language. For verbalization of the professional concepts and cognitive structures transformed from the "alien" conceptual space, both the own language means and foreign words are used. In addition to the nominative function, foreign language verbalizers are able to perform the role of detail senders.

In addition, borrowed sports terms that verbalize the professional concept in the recipient language reflect the conceptual structure generated on the basis of the already existing mental structures in the donor language. The transformation of a "alien" professional concept is carried out in different ways. Mostly, a model is used to transform English language concepts with the initial structure of the prototype concept. The model of narrowing of the structure of the original concept is less frequent. Single cases are models with a change in the degree of dominance of a trait in the recipient language and with the development of new conceptual traits in the receiving language.

The study of the features of foreign language sports terms transformation into German in the cognitive perspective has shown that foreign language verbalizers most often convey a conceptual structure in the recipient language, which is generated on the basis of already existing mental structures in the donor language. This fact allowed us to define various cognitive models of transformation of the "alien" concept: preserving the original structure of the concept prototype; a change in the degree of the trait in the recipient language; the development of new conceptual features in the host language; the narrowing of the structure of the concept prototype. The proposed list of cognitive models is not exhaustive; it can be further supplemented taking into account the features of terminological borrowing identified in this study.

In general, this study has demonstrated that borrowed sports terms have heuristic potential in the German-speaking space and the ability to translate professional sports knowledge.

The main perspective of this study is seen in considering the cognitive features of terminological borrowing in other areas of professional activity, as well as in further developing the theory of borrowing in relation to terminological units in languages of various types based on the study of the interaction of mental and linguistic structures. 
Cognitive Models of Concepts Transformation in Some German Sports Terms Borrowed from English

\section{النماذج المعرفية لتحويل المفاهيم المهنية، التي تمت كتابتها بشروط مستعارة باللفة الإنجليزية في المجال الرياضي للفة الألمانية \\ لاريسا ميروشنيشنكو، إيلينا موسيليان \\ قسم اللفة الإنجليزية، جامعة بيلفورود الحكومية الوطنية للبحوث، روسيان \\ لاريسا فورونينا \\ قسم اللفتين الألمانية والفرنسية، جامعة بيلفورود الحكومية الوطنية للبحوث، روسيا

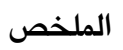

يتناول المقال الجوانب اللفوية لعملية استعارة المصطلحات من اللفة الإنجليزية إلى المجال الرياضي للفة الألمانية من منظور النهج المعرفي .ويحلل ميزات التفاعل المعرفي للأنظمة المفاهيمية للمجالات المهنية، وتصف الدراسة نماذج تحول الهياكل المعرفية إلى اللفة المتلقية في عملية استعارة المصطلحات على المواد الرياضية الأنجليكيسية للفة الألمانية. وتوضح أن كلمات القروض تنقل في الغالب بنية مفاهيمية في لغة المستلم التي يتم إنثاؤها على أساس الهياكل العقلية الموجودة بالفعل في اللفة المصدر . ويتم تعريف النماذج المعرفية المختلفة لتحويل مفهوم" الأجنبي" مع الحفاظ على الهيكل الأصلي لمفهوم النموذج الأولي ؛ مع تطوير ميزات مفاهيمية جديدة في لغة المستله؛ مع تضييق الهيكل المفاهيمي للنموذج المثالي. ويساهم البحث في مشكلة تمثيل المعرفة في المصطلح، وتحديد الآليات اللغوية والمعرفية لتمثيل المعرفة من خلال الوحدات اللفوية المستعارة. ويمكن استخدام النتائج في تطوير دورات في اللفويات المعرفية، وقاموس المعجم، وممارسة البحث والأوصاف المعجمية، وكذلك في تدريس مهارات اللفة العملية في الرياضات الاحترافية. الكلمات المفتاحية :الاستعارة، المصطلحات، المصطلحات الرياضي ، المصطلحات المعرفية، المعرفة المهنية. 


\section{References}

DWDS. n.d. s.v. "Spurt.” Accessed March 29, 2021. http:// https://www.dwds.de/wb/Spurt.

Room, Adrian. 2010. "Drop cick." In Dictionary of Sports and Games Terminology. McFarland \& Company, Inc., Publishers.

Epimakhova, A.Yu. 2011. Cognitive-communicative approach to borrowing in the professional areas of the language. Bulletin of Chelyabinsk State University. Issue 57. Philology. Art Criticism 24 (239): 137-139.

Golovanova, Elena.I. 2011. Introduction to cognitive Terminology. Moscow: Flint, Science.

Haugen, Einar. 1972. "The Process of Borrowing”. In the New in linguistics: Language contacts, vol. 6, 344-382. Moscow: Progress.

Ilyina, L.A., Sytcheva O.V. 1998. Lexical Borrowing: The Transition of Foreign Language or IntraLanguage Creation. Humanities in Siberia. Philology series 4: 91-96.

Krysin, Leonid Petrovich. 2004. The Russian Word, Own and Someone Else's: Studies on the Modern Russian Language and Sociolinguistics. Moscow: Languages of Slavic culture.

Leychik, V.M. 2012. Terminology: Subject, Methods, Structure. 5th ed, rev. and add. Moscow: Book House "LIBROCOM".

Dobrodomov, I.G. 1998. "Borrowing.” In Linguistics. Large Encyclopedic Dictionary, edited by. V.N. Yartseva. (2nd ed.) Moscow: Great Russian Encyclopedia.

Novodranova, V. F. 2012. Classification of Knowledge and Channels of Their Obtaining in Special Fields of Scientific Activity (On the Material of Formation of Medical Terminology). Actual Problems of English Linguistics: To the Jubilee of Professor O. V. Alexandrova: 362-370.

Paul, G. 1960. Principles of the History of Language. Moscow: Publishing House of Foreign Literature.

Random House Kernerman Webster's College Dictionary. http://www.thefreedictionary.com.

Pavilionis, R. 1983. The Problem of Meaning. Modern Logical and Philosophical Analysis of Language. Moscow: Mind.

Weisgerber, Johann Leo. 2004. Mother Tongue and Spirit Formation. 2nd ed., rev. and add. Moscow: Editorial URSS.

Wikipedia. 2021. S.v. "Hat-trick." Last modified March 29, 2021. http:// https://en.wikipedia. org/wiki/ Hat-trick. 